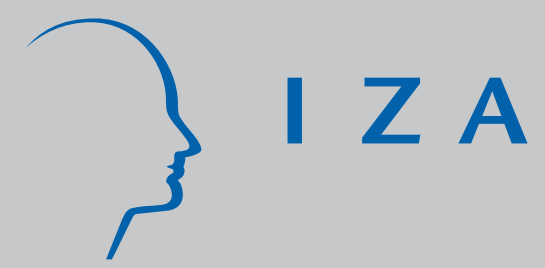

IZA DP No. 6378

The Pitfalls of Work Requirements in Welfare-to-Work Policies: Experimental Evidence on Human Capital Accumulation in the Self-Sufficiency Project

Chris Riddell

W. Craig Riddell

February 2012 


\title{
The Pitfalls of Work Requirements in Welfare-to-Work Policies: Experimental Evidence on Human Capital Accumulation in the Self-Sufficiency Project
}

\author{
Chris Riddell \\ ILR School, Cornell University \\ W. Craig Riddell \\ University of British Columbia \\ and IZA
}
Discussion Paper No. 6378
February 2012

\author{
IZA \\ P.O. Box 7240 \\ 53072 Bonn \\ Germany \\ Phone: +49-228-3894-0 \\ Fax: +49-228-3894-180 \\ E-mail: iza@iza.org
}

Any opinions expressed here are those of the author(s) and not those of IZA. Research published in this series may include views on policy, but the institute itself takes no institutional policy positions.

The Institute for the Study of Labor (IZA) in Bonn is a local and virtual international research center and a place of communication between science, politics and business. IZA is an independent nonprofit organization supported by Deutsche Post Foundation. The center is associated with the University of Bonn and offers a stimulating research environment through its international network, workshops and conferences, data service, project support, research visits and doctoral program. IZA engages in (i) original and internationally competitive research in all fields of labor economics, (ii) development of policy concepts, and (iii) dissemination of research results and concepts to the interested public.

IZA Discussion Papers often represent preliminary work and are circulated to encourage discussion. Citation of such a paper should account for its provisional character. A revised version may be available directly from the author. 


\section{ABSTRACT \\ The Pitfalls of Work Requirements in Welfare-to-Work Policies: Experimental Evidence on Human Capital Accumulation in the Self-Sufficiency Project ${ }^{*}$}

This paper investigates whether policies that encourage recipients to exit welfare for full-time employment influence participation in educational activity. The Self-Sufficiency Project ('SSP') was a demonstration project where long-term welfare recipients randomly assigned to the treatment group were offered a generous earnings supplement if they exited welfare for full-time employment. We find that treatment group members were less likely to upgrade their education along all dimensions: high-school completion, enrolling in a community college or trade school, and enrolling in university. Thus, 'work-first'; policies that encourage full-time employment may reduce educational activity and may have adverse consequences on the long-run earnings capacity of welfare recipients. We also find that there was a substantial amount of educational upgrading in this population. For instance, among high-school dropouts at the baseline, $19 \%$ completed their diploma by the end of the demonstration. Finally, we simulate the consequences of the earnings supplement in the absence of adverse effects on educational upgrading. Doing so alters the interpretation of the lessons from the SSP demonstration.

JEL Classification: $\quad 138, \mathrm{J08}, \mathrm{J} 24$

Keywords: welfare policy, human capital, experimental methods, earnings supplementation

Corresponding author:

W. Craig Riddell

Department of Economics

University of British Columbia

\#997-1873 East Mall

Vancouver, BC V6T $1 Z 1$

Canada

E-mail: criddell@interchange.ubc.ca

\footnotetext{
We thank SRDC and the SSHRC for research support and Rebecca Blank, David Card, David Green, Bob Gregory, Kevin Milligan, Thomas Lemieux, Phil Oreopoulos and Doug Tattrie for helpful comments. We have also benefited from presentations at HEC Montreal, Simon Fraser University, the Australian Labour Market Research Workshop at ANU, and the meetings of the Canadian Economics Association and the Society of Labor Economists.
} 


\section{Introduction}

A central issue in the design of social programs is minimizing adverse consequences. In structuring their welfare programs many countries have struggled with the conflicting objectives of providing adequate support to low-income families, encouraging work and achieving low government costs. Much economic research has been devoted to understanding the effects of program design on work incentives. Impacts on family composition and fertility have also received attention. Little is known, however, about the subject of this paper - the impacts of welfare programs on educational attainment.

During the 1990s traditional welfare programs were substantially restructured in the U.S. and several other countries. A central goal of these reforms was to encourage work and economic self-sufficiency. Although much has been learned about the consequences of these policy changes, several unresolved issues remain. One contentious issue involves the choice between “work-first” and "human capital development” approaches to achieving self-sufficiency. The work-first approach -- which emphasizes moving recipients into jobs quickly, even if at low initial wages -- reflects the view that welfare recipients can best acquire work habits and skills at the workplace. In contrast, the human capital approach seeks to raise the long term earnings capacity of welfare recipients by providing training and educational opportunities.

A noteworthy feature of recent welfare policies has been the emphasis on financial incentives. Many U.S. states have experimented with welfare-to-work programs since the early 1980s. The replacement in 1996 of the Aid to Families with Dependent Children program with the Temporary Assistance for Needy Families block grant gave states much more discretion in the design of their welfare programs. This greater authority, together with federal targets for work requirements, led to increased use of financial incentives. Unlike the negative income tax 
programs evaluated in the 1960s and 1970s, recent financial incentives often emphasize full-time employment (Blank, Card and Robins, 2000).

This paper makes three contributions. First, we contribute to the debate over alternative approaches to welfare reform by investigating whether policies that provide a financial incentive to exit welfare for full-time work influence participation in educational activity. As noted by Moffitt (2002), the effects of transfer programs on human capital investment have received little attention. ${ }^{1}$ By raising the return to existing skills, such policies may reduce the incentive to invest in additional education. In addition, by encouraging full-time participation in the workforce they reduce the time available for other activities, including acquiring further education. Earnings supplements that are conditional on full-time employment may thus inadvertently reduce the long run earnings capacity of welfare recipients. Our investigation provides rather striking evidence that this may indeed be the case.

The second contribution of this study is to advancing our understanding of the factors that influence the behavior of welfare recipients. Most economic analysis of income support policies employs a static choice framework. ${ }^{2}$ Central to this workhorse model is the way that alternative policies alter the budget constraint faced by current and potential program participants. Our analysis highlights two aspects of behavior that standard models often abstract from. One is the time constraint. Raising young children and upgrading one’s formal schooling are activities that compete with market work for available time. The second is forward-looking behavior, a feature emphasized by Miller and Saunders (1997), Keane and Wolpin (2002) and others. In our setting, investing in additional education involves incurring time and financial costs today in return for

\footnotetext{
${ }^{1}$ The principal exception is Miller and Saunders (1997) who examine the impact of state-level generosity of welfare on high school completion. Kesselman (1976) makes the point that, for those expecting to remain on public assistance, welfare reduces the incentive to invest in education.

${ }^{2}$ See Moffitt (2002) for a survey of the literature on welfare programs and labor supply.
} 
expected future benefits. Our results indicate that taking into account the longer-term consequences of current decisions is important to understanding the behavior of welfare recipients.

To address these issues we employ data from the Self-Sufficiency Project (SSP), a demonstration project designed to provide a rigorous test of a temporary earnings supplement. The SSP was carried out in the Canadian provinces of British Columbia and New Brunswick during the 1990s and was evaluated using a random assignment design. The treatment involved a generous earnings supplement for those leaving welfare to take full-time employment.

The paper's final contribution is to enhancing our understanding of the lessons from the SSP demonstration itself. A central objective of the experiment was to test the theory that a temporary earnings supplement could have long-term impacts on employment, earnings and welfare receipt. By providing recipients with a strong financial incentive to exit welfare and take up full-time work, treatment group members would gain additional work experience, potentially leading to higher wages and improved employment opportunities. Preferences between work and non-work activities might also be altered by increased exposure to the workplace. As a consequence, work could become a better alternative to welfare after the end of the earnings supplement.

The results of the SSP demonstration have led many observers to conclude that temporary earnings supplements are unlikely to have long-lasting impacts. Although the financial incentive offer did result in a large decline in welfare receipt and a substantial increase in employment during the supplement period, by the end of the SSP demonstration there were no significant differences between treatments and controls in employment or welfare receipt (Michalopoulos et. al 2002). However, our results suggest that providing a financial incentive for full-time employment can have both positive and negative effects on human capital accumulation of 
welfare recipients. The former arise from additional work experience, and the negative impacts arise from reduced investment in formal education. Whether the overall impact is positive or negative depends on the magnitudes of these offsetting effects. This radically different interpretation of the lessons from the SSP follows from the unintended consequences on educational upgrading of providing incentives to work full-time.

Our examination of SSP data indicates that increases in educational attainment among current and former welfare recipients are quantitatively important. Based on our preferred sample, about $19 \%$ of those who were high school dropouts at the time of the baseline survey had completed secondary school by the 54-month survey. Among those who had graduated from high school at the baseline, substantial educational activity is also evident in the form of enrolment in community colleges and universities. The extent of educational upgrading suggests that this is a phenomenon worthy of investigation.

A key finding of the paper is that the offer of a financial incentive to exit welfare and take full-time employment reduced educational upgrading among SSP participants. The impact of the supplement offer on educational activity was largest in the first 18 months after random assignment, when the difference in full-time employment between the treatment and control groups was the largest. We conclude that encouraging full-time employment has potentially adverse consequences for the long-term earnings capacity of single parents on welfare.

Another conclusion is that the SSP experimental impacts may have caused observers to reach incorrect conclusions about the long-term effects of temporary earnings supplements, and the mechanisms by which such effects occur. Those who upgraded their formal education achieved gains in employment and reductions in welfare receipt relative to their counterparts who did not acquire additional education. The gains experienced by “upgraders” appear to be principally a 
consequence of their investments in education rather than being due to unobserved factors that are correlated with both the propensity to acquire education and individual outcomes. We simulate the impacts of the SSP financial incentive on welfare receipt in the absence of any impact on educational upgrading. Our simulation results suggest that in these circumstances the temporary earnings supplement would have long-lasting effects.

The paper is organized as follows. The next section provides background on the SSP demonstration. Section 3 outlines a simple economic model that motivates the empirical analysis and helps to interpret the results. The fourth section describes the data used in our investigation. Section 5 analyses the impact of the SSP financial offer on educational upgrading, utilizing the random assignment feature of the research design. Particular focus is given to high school completion among secondary school dropouts and university enrolment among high school graduates. This part of the analysis examines whether full-time work requirements reduce the amount of formal educational upgrading that would have otherwise occurred. Section 6 examines the extent to which our empirical results lead to a re-assessment of the implications of the SSP experiment. The final section concludes.

\section{Background}

Alternative welfare-to-work strategies have been extensively debated. A particularly contentious issue is whether to encourage welfare recipients to enter the work force with their existing skills or to help them to acquire additional human capital. As discussed by Blank (2002), evaluations indicate that the work-first strategy increases earnings and reduces welfare receipt to a greater extent than does the human capital strategy, at least in the short run (two to three years after entry into the program). However, human capital strategies may be superior over longer time horizons. For example, using data from California’s GAIN program - a program that adopted a 
variety of welfare-to-work strategies - Hotz, Imbens and Klerman (2006) find that recipients who participated in human capital programs did as well as or better than those in work-first programs in years 7 to 9 after the program.

In this paper we examine the consequences of a particular variant on the work-first strategy one that provides a powerful financial incentive to obtain and maintain full-time employment. Our objective is not to contrast this policy with one that provides educational and training opportunities. Rather, we seek to understand whether welfare-to-work programs that focus on encouraging full-time employment may retard gains in formal education that would otherwise occur. To our knowledge this possibility has not been previously examined. ${ }^{3}$

Recent welfare reforms have substantially reduced caseloads, but there is little evidence of increased income among former participants (Blank, 2002). One explanation for this situation is that many states have adopted earnings disregards that tend to encourage part-time employment - which is unlikely to reduce poverty. For this reason, analysts such as Robins and Michalopoulos (2001) have advocated financial incentives that encourage welfare leavers to work full-time. ${ }^{4}$ The SSP is a leading example of this approach. ${ }^{5}$

During the 1990s the Canadian government funded an innovative demonstration project, the SSP, designed to provide evidence on the effects of a financial incentive on long-term welfare recipients. ${ }^{6}$ The SSP focused on single parents with children. ${ }^{7}$ Among those who agreed to

\footnotetext{
${ }^{3}$ Most of the analysis of the Negative Income Tax (NIT) experiments carried out in the 1960s and 1970s focused on the labor supply effects, but some studies did examine the impacts on education. However, the emphasis in these studies was on the impact of a NIT on the work-school choices of youths in experimental families and on scholastic performance of school-age children in these families. Hanushek (1986) reviews this evidence.

${ }^{4}$ Conditioning benefits on full-time employment also minimizes reductions in labor supply such as those that would occur under a conventional NIT.

${ }^{5}$ Indeed, Robins and Michalopoulos (2001) base their simulations of the consequences of adopting this approach in the U.S. on results from the SSP.

${ }^{6}$ Long-term was defined as having been on welfare for at least 12 of the past 13 months. For details of the SSP demonstration see Michalopoulos et. al (2002).

${ }^{7}$ In Canada welfare (often referred to as income or social assistance) is not restricted to single parents with children.
} 
participate, one-half were randomly assigned to the treatment group that was eligible for the earnings supplement; the rest were assigned to the control group. Those in the treatment group were offered a financial incentive to leave welfare and take up full-time employment. ${ }^{8}$ The financial incentive was generous, approximately doubling income from work for the typical participant and providing total income substantially higher than welfare benefits. ${ }^{9}$

The SSP demonstration incorporated two important time limits. Members of the treatment group were given up to 12 months following random assignment to obtain full-time employment. Once they had qualified, participants could continue to receive the supplement for three years providing they maintained full-time employment. Those in the control group could remain on welfare or enter the workforce. Card and Hyslop (2005) show that the two SSP time limits generated an "establishment" incentive to find a full-time job and exit welfare within 12 months after random assignment, and an "entitlement" incentive to choose work over welfare once eligibility was established. Accordingly we look for differences in educational activity during the first year after random assignment and during the subsequent three years.

The experimental findings are summarized in the SSP Final Report (Michalopoulos et. al. 2002). More than one-third of the treatment group obtained full-time employment and qualified for the earnings supplement. During the SSP eligibility period, the treatment group experienced substantial gains in earnings and employment and reduced welfare use relative to the control group. The largest impacts - differences in employment rates and welfare receipt of approximately 14 percentage points -- were observed during the first 12-15 months following random assignment. After this time the differences in outcomes between the treatment and

\footnotetext{
${ }^{8}$ Full-time employment was defined as at least 30 hours per week and could be achieved by combining two or more part-time jobs.

${ }_{9}^{9}$ Blank, Card and Robins (2000) review seven financial incentive welfare-to-work programs evaluated by random assignment in the U.S. and Canada during the 1990s. The SSP earnings supplement was the most generous of this group.
} 
control groups narrowed. ${ }^{10}$ By the end of the 3-year period of supplement eligibility treatmentcontrol differences in employment, earnings and welfare receipt were small. ${ }^{11}$

However, there were important differences in behavior between the two provinces, a feature of the experiment that has not previously been adequately explained. Treatment - control differences in employment and welfare use persisted much longer in New Brunswick than in British Columbia. ${ }^{12}$ We discuss these provincial differences, and provide an explanation for them, later in the paper.

A noteworthy feature of the SSP design was that it generated large differences in full-time employment rates between the treatment and control groups, especially during the first 12 to 15 months after random assignment. Compared to other welfare-to-work programs that provide a financial incentive to exit welfare, the SSP provides a unique setting for examining the consequences for educational attainment of emphasizing full-time work.

\section{Model}

In this section we outline a simple economic model that motivates the empirical analysis and helps to interpret the results. The model has several key features. First, as in Keane and Wolpin (2002), welfare recipients are forward looking; decisions made today may affect opportunities and constraints in the future. Second, reflecting the fact that all of those in the experimental sample volunteered to participate in the SSP, recipients are potentially interested in achieving self-sufficiency. One way to do so - the method emphasized in previous analysis of the SSP -- is to enter the labor force and accumulate work experience that may raise future earnings. The

\footnotetext{
${ }^{10}$ See Michalopoulos et. al (2002), Figures 3.1 and 3.2.

${ }^{11}$ At the 52-month point the employment rates of the two groups were approximately equal and not significantly different from each other (Michalopoulos et. al. (2002). The fraction receiving welfare converged by month 70 (Card and Hyslop, 2005).

${ }^{12}$ For example, in the second quarter of year 5 the employment difference was -2.0 (with a standard error of 1.7) in $\mathrm{BC}$ versus +5.4 (standard error $=1.8$ ) in NB (Michalopoulos et. al. (2002).
} 
alternative is to acquire additional formal education, which may also increase earnings potential. Although the potential benefits of investing in education have been considered in other dynamic contexts (e.g. Keane and Wolpin, 2000), they have not previously been considered in analyzing the SSP, nor have they received much attention in the broader welfare-to-work literature.

A third feature is recognition of the time constraint. Upgrading one’s education or working full-time reduces time available for caring for children and other household production. The final key characteristic of the model is the presence of heterogeneity in preferences and constraints. Some welfare recipients are more "job ready" than others, due to such factors as more education and/or work experience and better language or other skills. They thus face lower costs of obtaining full-time employment and higher potential wages. Likewise, some individuals would find it more costly to complete an educational program because doing so would require completing more courses or involve greater psychic costs associated with additional schooling.

We first outline the model that applies to those not eligible for the earnings supplement, i.e. those in the SSP control group. The model has three periods. In period 0 each single parent is on income assistance (welfare) receiving benefits $b_{\mathrm{i}}$. In period 1 each recipient can choose one of three mutually exclusive options: (i) enter the labor force and search for full-time employment, (ii) enter an educational program such as one leading to a high school diploma or university degree, and (iii) remain on income assistance without undertaking option (i) or (ii). Those who select the first option are denoted by $\mathrm{JS}_{\mathrm{i}}=1$, and those selecting option 2 by $\mathrm{EU}_{\mathrm{i}}=1$. Those with $\mathrm{JS}_{\mathrm{i}}=0$ and $\mathrm{EU}_{\mathrm{i}}=0$ remain on welfare or income assistance $\left(\mathrm{IA}_{\mathrm{i}}=1\right)$ receiving welfare benefit $\mathrm{b}_{\mathrm{i}}$.

For those choosing to enter the labor force there is a cost of searching for work $\mathrm{CS}_{\mathrm{i}}$ that varies across individuals depending on their "job readiness." Those who incur this cost receive a wage offer $\mathrm{W}_{\mathrm{i}}$ drawn from a distribution of wage offers. In the base period each single parent 
knows $\mathrm{CS}_{\mathrm{i}}$ and the distribution of wage offers that $\mathrm{W}_{\mathrm{i}}$ would be drawn from. Not all those who choose to search for full-time employment (and thus incur search costs $\mathrm{CS}_{\mathrm{i}}$ ) receive a wage offer high enough to accept the offered job. Among those who accept the offer, wages evolve according to

$$
\mathrm{W}_{2 \mathrm{i}}=k_{\mathrm{i}} \mathrm{W}_{1 \mathrm{i}}
$$

where $k_{\mathrm{i}}$ is the return to work experience for individual $\mathrm{i}$. Those who do not accept the wage offer remain on welfare, receiving benefit $b_{i}$.

Single parents that return to school incur schooling costs $\mathrm{CE}_{\mathrm{i}}$. These individuals continue to receive welfare benefits $b_{i}$ in period 1 , but have less time available for childcare and household production than their counterparts who do not return to school. In period 2 they enter the workforce and obtain employment at wage

$$
\mathrm{W}_{2 \mathrm{i}}=s_{\mathrm{i}} \mathrm{W}_{1 \mathrm{i}}
$$

where $s_{\mathrm{i}}$ is the return to schooling and $\mathrm{W}_{1 \mathrm{i}}$ is the wage offer that individual $\mathrm{i}$ would have received if she had entered the labor force in period 1.

The optimizing choices for each recipient are obtained by backward induction. There are numerous sources of heterogeneity in the model: search costs $C S_{i}$, wage offers conditional on job search $\mathrm{W}_{\mathrm{i}}$, returns to work experience $k_{\mathrm{i}}$, costs of obtaining additional education $\mathrm{CE}_{\mathrm{i}}$, and returns to additional education $s_{\mathrm{i}}$. For illustrative purposes we focus on two sources of heterogeneity: costs of obtaining an offer of full-time employment $\mathrm{CS}_{\mathrm{i}}$ and costs of obtaining additional education $\mathrm{CE}_{\mathrm{i}}$. The distributions of these costs produce four groups of welfare recipients:

1) those for whom $C S_{i}$ and $C E_{i}$ are sufficiently large that they choose $I A_{i}=1$;

2) those who choose $J S_{i}=1$ but receive a wage offer sufficiently low that they remain on welfare $\left(\mathrm{IA}_{\mathrm{i}}=1\right)$; 
3) those who choose $\mathrm{JS}_{\mathrm{i}}=1$ and accept the wage offer, receiving the wage $\mathrm{W}_{1 \mathrm{i}}$ in period 1 and $\mathrm{W}_{2 \mathrm{i}}$ in period 2;

4) those who choose $\mathrm{EU}_{\mathrm{i}}=1$, receiving income $\mathrm{b}_{\mathrm{i}}$ in period 1 and the wage $\mathrm{W}_{2 \mathrm{i}}$ in period 2 .

The model predicts cut-off values that separate recipients into these groups. ${ }^{13}$ Denote the cut-off values $\mathrm{CS}_{\mathrm{i}} *$ and $\mathrm{CE}_{\mathrm{i}}^{*}$ that yield groups of size $\mathrm{N} 1 *$ in groups 1 and $2, \mathrm{~N} 2 *$ in group 3 and N3* in group 4. The behavior of the SSP control group provides unbiased estimates of the number of single parents in each of these three groups. Denote these estimates by $N 1^{*}, N 2 *$ and N3*.

Now consider those randomly assigned to the SSP treatment group. Because of random assignment, the group sizes $N 1^{*}, N 2 *$ and $N 3^{*}$ are unbiased estimates of the outcomes that would be observed for the treatment group in the absence of the SSP supplement offer.

The offer of an earnings supplement alters the incentives that single parents face by enhancing the income associated with full-time employment. The comparative static predictions of the supplement offer are unambiguous. Those who choose to search for work $\left(\mathrm{JS}_{\mathrm{i}}=1\right)$ and accept the wage offer now receive income $\mathrm{W}_{1 \mathrm{i}}+\mathrm{ES}\left(\mathrm{W}_{1 \mathrm{i}}\right)$ in period 1 and $\mathrm{W}_{2 \mathrm{i}}+\mathrm{ES}\left(\mathrm{W}_{2 \mathrm{i}}\right)$ in period 2. This lowers the cut-off value of $\mathrm{CS}_{\mathrm{i}}$, and reduces the size of group 1 to $\mathrm{N} 1 * *<\mathrm{N} 1 *$ and increases the size of group 2 to $\mathrm{N} 2 * *>\mathrm{N} 2 *$. This is the familiar predicted impact of the offer of an earnings supplement analyzed in previous studies.

However, the offer of an earnings supplement also alters the choice between searching for work and acquiring additional education. Those who enter the labor force directly in period 1 receive the earnings supplement in periods 1 and 2 , while those who enter the labor force in period 2 after acquiring additional schooling receive the earnings supplement only in period 2 . The supplement offer is predicted to reduce the number of individuals acquiring additional

\footnotetext{
${ }^{13}$ Details of the cut-off values and comparative statics predictions are available on request.
} 
schooling $\left(\mathrm{N}^{* *}<\mathrm{N} 3^{*}\right)$ and to increase the number of recipients directly entering the labor force. The comparative statics predictions $\mathrm{N} 2 * *>\mathrm{N} 2 *$ and $\mathrm{N} 3 * *<\mathrm{N} 3 *$ are tested in section 5 .

\section{Data}

Participants in the SSP demonstration were surveyed at the baseline, and after 18, 36 and 54 months. In addition, monthly administrative data on welfare receipt and employment is available. The full data set consists of 5978 observations. We exclude the 293 individuals in the SSP+ program, which involved a different treatment. ${ }^{14}$ We also exclude the 833 individuals who did not respond to the 54 month survey since we have no educational attainment and enrolment data post 36 months for such persons. ${ }^{15} 16$ Our final sample thus consists of 4852 individuals.

The surveys contain two principal sources of information that can be used to characterise education upgrading. One source utilizes the enrolment and educational attainment questions. Each survey asks whether the individual: a) graduated from high school; b) was ever enrolled in a community college or trade school, and if so whether they obtained a certificate or diploma from that schooling; and c) was ever enrolled in a university, and if so whether they obtained a university certificate, diploma or degree. Additional information on education upgrading is provided by the course work questions, available from the 18 through 54-month surveys. These questions ask respondents whether they have taken any work or non-work related courses since the previous survey. Individuals who respond positively are then asked whether these courses were work-related or non-work (education) related. The education questions were either identical or very similar across all four surveys.

\footnotetext{
${ }^{14}$ SSP Plus was a variant designed to test the combination of the SSP financial incentive and additional services such as resume writing, job clubs and employment counseling.

${ }^{15}$ A regression of a SSP treatment dummy on a dummy equal to one for not responding to the 54 month survey reveals that there was no statistically significant difference between treatments and controls in survey non-response after 36 months.

${ }^{16}$ We have, however, examined the experimental effect of the SSP on educational attainment including individuals who missed the 54-month survey, using the methods outlined in the appendix for dealing with missing data. The results are unchanged and are available upon request.
} 
Appendix Table A1 shows all possible combinations of responses to the high-school completion question over time and the number of responses for each combination. Some responses to the high school completion question are not consistent with the fact that educational attainment can increase but cannot decrease over time. In addition, not all participants responded to each of the four surveys. We deal with measurement error and missing data in several ways, as described in the appendix. The results are not sensitive to these alternative sample restrictions. In what follows we present findings based on our preferred sample; results based on alternative samples are reported in the appendix.

\section{The experimental impact of the SSP supplement offer on educational attainment}

We now examine whether there were differences between the treatment and control groups in acquiring additional schooling during the 54 months of the SSP demonstration. Consistent with the emphasis on heterogeneity in our theoretical model, we analyse educational upgrading for two distinct groups - those who had and had not completed high school at the baseline. Because these sub-samples of "potential upgraders" condition on a baseline characteristic, each subsample should be as good as randomly assigned to the treatment and control groups. Table 1 reports mean baseline characteristics for these sub-samples. Most are unmarried mothers, with average age of 32 years. More than one-half of the full sample had not completed high school at the baseline. These single parents spent almost all of the previous year on welfare, as was required for participation in the SSP demonstration. Nonetheless, they have considerable previous work experience, with dropouts reporting over 6 years and high school graduates over 8 years of experience. Other differences between the two sub-samples (which are generally modest in nature) are evident in the number of children (higher among dropouts), whether ever married 
(less likely among dropouts), immigrant status (graduates are more likely to have been born outside Canada) and disability status (dropouts are more likely to report being disabled).

The baseline survey also included questions about attitudes towards work and welfare. Over $60 \%$ of both groups agreed or strongly agreed with the statement "I am ashamed to admit to people that I am on welfare" and about 70\% agreed/strongly agreed with the statement "Its wrong to stay on welfare if you can get a job, even a job you don't like.” The most noteworthy difference between dropouts and graduates in responses to these attitudinal questions related to the desire for additional schooling. Those who had not completed high school were much more likely to agree/strongly agree with the statement "Right now I'd really like to be going to school to improve my reading and math skills.”

Consistent with the dropouts and graduates sub-samples being as good as randomly assigned, none of the mean characteristics is significantly different between the program and control groups. As an additional test of random assignment, we also conducted Kolmogorov-Smirnov tests on the equality of the distribution functions of the continuous variables. In each case, we were unable to reject the null hypothesis of equality of the distribution functions.

The top panel of Table 2 shows the evolution of high school completion using our preferred high school dropout sample of 2693 individuals. ${ }^{17}$ There is evidence of a substantial amount of educational change during the period. In each interval, members of the control group exhibited a greater increase in high school completion than their counterparts in the treatment group. By the

\footnotetext{
${ }^{17}$ In both provinces there are three ways adults may obtain a high school diploma. The first is to go back to a high school classroom setting and complete the regular secondary school curriculum. Very few adults receive their diploma in this manner. The second, and by far most popular, route is the adult high school diploma program known as Adult Dogwood in British Columbia and Adult High-School Diploma in New Brunswick. These programs are only for individuals age 19+ and are offered through the community college system. The major difference between the two provinces is that eligibility for the NB program is more stringent. The final route to a high school diploma is to challenge the exams. In NB this would involve writing the exam for the required courses and achieving $60 \%$ or more. In BC, at the time of the SSP, there were required provincial exams and thus students would have to challenge those as well as meet other graduation requirements. In both provinces there is no tuition for the adult high school diploma programs.
} 
end of the SSP, high school completion increased by 20.9 percentage points in the control group versus 16.8 percentage points in the treatment group, a differential of 4.1 percentage points. Appendix Table A2 reveals that the methods used to address measurement error and missing data do not significantly influence the results with the experimental effect ranging from 3.9 to 4.2 percentage points for high school completion. By this measure, the extent of educational upgrading in the treatment group is around $25-35 \%$ below that of the control group, a differential that is large in a behavioral sense and statistically significant.

The final column of Table 2 reports differences estimators that include a full set of baseline control variables in a high school upgrading regression. Under random assignment both the simple differences estimators in column 3 and the regression-controlled differences estimator in column 4 provide unbiased estimates of the impact of the SSP financial incentive on educational change. Comparison of these two estimators provides a further test of random assignment. As can be seen, the simple and regression-controlled differences estimates are virtually identical, providing further evidence that random assignment was preserved for our sub-sample of high school dropouts.

The timing of educational change is also noteworthy. The largest treatment - control differences in courses taken (not shown) occur in the first 18-month interval, when the difference in work activity between the two groups was greatest. In addition, the smallest gap in course work activity is evident in the final 18-month interval, when the employment rates of the treatment and control groups had substantially converged.

The bottom panel of Table 2 presents a similar analysis for enrolment in university. ${ }^{18} 19$ Compared to their counterparts in the program group, control group members were more likely

\footnotetext{
${ }^{18}$ The number of observations on university completion is too small to warrant analysis.
} 
to enrol in university programs, with a statistically significant difference of 1.8 percentage

points. Even at the university level the difference in educational activity between treatments and

controls is non-trivial in size and statistically significant.

There were also noteworthy differences between the two provinces in the impact of the financial offer on educational upgrading. Table 3 shows the provincial breakdowns. In both jurisdictions, and for both dropouts and graduates, the control group invests more in additional education than does the treatment group. However, the experimental impact is much larger in BC than in NB. Among those who were dropouts at the baseline, the treatment-control difference in completing secondary school is 5.7 percentage points in BC versus 2.6 percentage points in NB. The treatment-control gap in university enrolment is also more than double its NB counterpart. We explore these provincial differences further in the following section.

In summary, measures of educational upgrading at both the high school and university levels indicate that SSP participants made substantial additional investments in human capital during the demonstration. The differences between treatments and controls also imply that the SSP financial incentive resulted in less acquisition of additional schooling than would otherwise have been the case. The differential in educational activity between the treatment and control groups is substantial, whether measured by enrolment or credentials obtained. The timing of the upgrading is consistent with the view that the emphasis on full-time work reduced human capital

\footnotetext{
${ }^{19}$ There is also substantial educational activity at the community college and trade school levels, and significantly more enrolment in these courses among members of the control group. For example, the experimental impact on enrolment in college and trades school courses is -3.8 percentage points with a standard error of 1.5. We chose to focus on university enrolment for several reasons. Community colleges offer a very heterogeneous mix of courses and programs, including adult basic education and high school level courses as well as post-secondary programs. The programs also vary substantially in duration, from one-day seminars to two-year academic and vocational programs. Because many courses taken for the purposes of high school completion were delivered by community colleges, there is considerable risk of "double-counting" when using measures based on college enrolment. In addition these institutions offer general interest courses such as dance, theatre, bible studies, avalanche training and cosmology that may not constitute work-related human capital formation. As a consequence, university enrolment is a cleaner measure of educational activity at the post-secondary level. There is also less evidence of measurement error at the university than at the college level, perhaps reflecting the heterogeneous nature of college programs.
} 
accumulation of the treatment group because of a combination of reduced time available for nonmarket activities and lower incentives to acquire additional education.

\section{Education upgrading and our understanding of the SSP}

The experimental findings demonstrate that the control group invested more in formal education than the treatment group, particularly in British Columbia. While these results are arguably of primary importance for the design of welfare-to-work policies, our focus in this section is on a narrower question. Does this unintended consequence of the earnings supplement offer alter the lessons from the SSP demonstration itself? Two issues are examined. First, does the differential extent of educational change across provinces help us understand the different impacts of the earnings supplement offer in the two jurisdictions? Second, does the extra education attained by the control group help explain why income assistance receipt and full-time employment were so similar in the treatment and control groups at the end of the earnings supplement period?

Table 4 shows income assistance rates by province as well as pooled for the SSP period. In the period after the expiry of the SSP supplement, substantial differences in welfare receipt across provinces are evident, differences that have received little previous attention. ${ }^{20}$ In particular, the convergence in welfare that is often associated with the SSP is much more pronounced in British Columbia where income assistance receipt at the 54-month survey was virtually identical between program and controls for high school dropouts and roughly the same for graduates. For New Brunswick, however, there is a gap of 6 to 7 percentage points. ${ }^{21}$

These differences raise an obvious question: if there had been less education upgrading (as was the case in NB compared to BC), would the offer of a substantial earnings supplement

\footnotetext{
${ }^{20}$ The SSP Final Report (Michalopoulos et. al., 2002, chapter 4) notes these differences but does not offer an explanation. To our knowledge, no explanation has been put forward.

${ }^{21}$ As with all of our findings in this section, the general pattern is the same for full-time employment and so for brevity we leave those results to be available upon request.
} 
have had a more lasting effect on full-time employment and welfare receipt? To address this question we analyze the impact of educational upgrading on income assistance receipt for our two sub-samples. Our goal is to provide a back-of-the-envelope calculation of the extent to which the extra educational attainment of the control group contributed to the similar welfare and employment patterns of the treatment and control groups after the expiry of the SSP earnings supplement. In estimating the effects of educational upgrading on labor market outcomes an obvious econometric challenge is non-random selection into education upgrading. At the outset we note that we do not expect that selection into upgrading is likely to be a serious issue in our two sub-samples, which are narrowly defined and relatively homogeneous groups. The SSP data contains a rich set of individual characteristics, including attitudes toward work, school and welfare, allowing us to control to an important extent for remaining heterogeneity within these groups. We deal with selection into educational upgrading based on unobserved factors by exploiting the longitudinal nature of the data. An additional statistical issue is measurement error in educational attainment, particularly changes in attainment, as documented in Appendix A. We address measurement error in education using an instrumental variable approach. ${ }^{22}$

We begin with a simple longitudinal model as follows:

$$
Y_{i t}=\mathrm{x}_{i t} \beta_{1}+\mathrm{z}_{i} \beta_{2}+\beta_{3} \theta_{t}+\beta_{4} \theta_{t}^{*} \mathrm{z}_{i}+\mathrm{c}_{i}+v_{i t}
$$

where $Y_{i t}$ is income assistance receipt; $\mathrm{x}_{i t}$ is a vector of time-varying covariates which includes a dummy for either high school completion or enrolment in university; $\mathrm{z}_{i}$ is a vector of baseline controls; $\theta_{t}$ is a time effect; $c_{i}$ is a time-invariant, individual-specific fixed effect; and $v_{i t}$ is an error term that is independent of $\theta_{t}$ and $c_{i}$. We estimate (3) separately for the high school dropout

\footnotetext{
${ }^{22}$ Our approach is similar to that of Ashenfelter and Krueger (1994) who study the impact of education on earnings using data on identical twins. As is the case here, they face the twin problems of endogeneity of education and measurement error in attainment. They employ a family fixed effects specification to deal with the former and an IV approach for the latter.
} 
and graduate samples, as displayed in Table 1. We interact the SSP program dummy with the time dummies to capture the incentive effects of the earnings supplement offer on employment and welfare receipt of the program group. As is documented below, this works well as the predicted IA rates from our models are almost identical to the actual IA rates shown in Table 4.

We assume that all covariates, including the decision to upgrade education, are strictly exogenous conditional on the unobserved effect $c_{i}$. The assumption of selection into upgrading on the basis of individual-specific time-invariant effects is consistent with our theoretical model that emphasizes heterogeneity across individuals in the costs and benefits of additional education. For example, the distance to the closest community college will vary across individual high school dropouts but is unlikely to vary over time for a specific individual. To address measurement error in education we adopt an instrumental variable strategy, choosing the coursework variable discussed earlier as an instrument for education upgrading. Such measurement error would otherwise bias the estimated coefficient on educational change towards zero. As we have documented, the measurement error in educational upgrading is substantial, especially for the case of obtaining a high school diploma. Our operating assumption that the decision to upgrade is exogenous conditional on the unobserved effect $c_{i}$ remains with the IV approach. Under this assumption the use of the course work variable as an instrument for educational upgrading yields consistent estimates of the parameters in equation (3). ${ }^{23}$

Several pieces of evidence support the assumption that upgrading is exogenous conditional on $\mathrm{c}_{i}$. First, if we were to test the stronger assumption that upgrading is as good as randomly assigned we would be interested in establishing that upgraders and non-upgraders have similar mean characteristics (both observed and unobserved) and that the two groups have

\footnotetext{
${ }^{23}$ This can be seen by taking first differences of equation (3). The course work variable is uncorrelated with the error term in the first-differenced equation and highly correlated with the educational upgrading variable $\mathrm{x}_{i t}-\mathrm{x}_{i t-1}$.
} 
common trends in welfare receipt. Note that the common trends condition largely holds simply as a result of the SSP design: to qualify for the study participants must have been on welfare 11 of the 12 months pre-baseline. On mean characteristics, appendix Table A3 reports baseline characteristics of the future upgraders and non-upgraders separately by province for the high school dropout sample. In BC, where educational upgrading was more prevalent, none of the baseline characteristics of upgraders and non-upgraders is significantly different at the $5 \%$ level. A joint test of all baseline characteristics also fails to reject the null of equality. ${ }^{24}$ For NB, differences between upgraders and non-upgraders are more evident, especially in age, age of youngest child, marital status and disability status. However, even here the two groups are highly comparable in their responses to the attitudinal questions that probe (typically unobserved) motivational characteristics. There are no statistically significant differences in the responses of the two groups on attitudes toward welfare, in their desire to be going to school, and whether they "like to work". In the high school graduate sample, the mean characteristics for university enrollees and non-enrollees are even more similar than for the dropout sample. ${ }^{25}$

Finally, as discussed in more detail below, we also carry out a falsification test for our assumption about upgrading. This falsification test easily passes. Overall, it is not clear that - at least for these two relatively homogeneous groups - selection on unobservables into upgrading education is a serious issue, especially in BC. In any event, our specification deals with selection into upgrading on the basis of person-specific fixed effects, which seems a reasonable assumption in this setting.

\footnotetext{
${ }^{24}$ We regressed the upgrading dummy on the full set of baseline characteristics, and tested their joint contribution to explaining upgrading. The F-statistic on the null hypothesis that all coefficients except that on the constant equals zero equals 1.79 , which is insignificant at the $5 \%$ level.

${ }^{25}$ The F-statistics corresponding to the test reported in the previous footnote were 1.4 for BC and 1.3 for NB. Only one individual characteristic was significantly different at the $5 \%$ level.
} 
Table 5a presents the results from estimating equation (3) by fixed-effects and two-stage fixed-effects estimation for BC while Table $5 \mathrm{~b}$ shows the same results for NB. ${ }^{26}$ For comparison purposes we also show pooled-cross-sectional results estimated by OLS and two-stage least squares. We note that the IV strategy overall appears to work reasonably well. The IV estimates are larger, consistent with the measurement error in the education variables. As one would expect, particularly in the fixed-effects case, standard errors increase substantially. Perhaps more interestingly, we note that the fixed-effects estimator does not appear necessary: the OLS pooledcross-sectional estimates are very similar to the fixed-effects estimates and similarly for the IV results. Consistent with the previous discussion, selection into upgrading on the basis of unobserved factors for these relatively homogeneous groups may not be quantitatively important.

As a further check on the specification, we carried out a falsification test for the high school dropout sample. The test utilizes information on education upgrading between each survey pair, and examines whether single parents who subsequently upgrade were less likely to be on welfare prior to improving their educational attainment. The results, reported in Table 6, demonstrate that this pre-treatment alignment test easily passes at each post-baseline survey date. We find no evidence that those who later complete high school had, prior to doing so, unobserved characteristics that are associated with lower welfare use.

Table 7 presents the results of our policy simulation. These provide estimates of the behavior of welfare receipt through the SSP period under the counterfactual in which none of the dropouts - i.e., both program and control group members - completed their high school diploma. Similarly, we simulate welfare patterns for the high school graduate sample under the

\footnotetext{
${ }^{26}$ In the Table 5 estimates the only time-varying covariates are those for educational change. Adding other timevarying covariates such as marital status doesn’t alter the results.
} 
counterfactual assumption that no one enrolled in university. Table 7(a) displays results for the high school dropout sample while Table 7(b) contains simulations for the sample of graduates.

The simulations indicate both the role of human capital accumulation in explaining welfare patterns, but also - of more interest to us in this paper - whether there would have been convergence in income assistance receipt over the SSP demonstration if education attainment had remained the same for the program and control groups. Recall that the predicted welfare rates from our model are nearly identical to the actual rates as seen earlier in Table 4; this is largely due to our specification, which includes time dummies, a random assignment dummy, and (importantly) interactions between random assignment and time period (along with the other baseline controls). Thus our specification incorporates all factors (such as greater income and work experience accumulated by the program group during the SSP demonstration) that influence the time pattern of welfare receipt of the program and control groups. Finally, we note that our simulations are based on the IV fixed-effect regression estimates, but are virtually identical to the simulations if we use the IV estimates from the pooled cross-sectional case as is obvious from the similarity of the estimates for the two estimation procedures. The one exception is for NB in the high school dropout sample where we find no effect of upgrading on welfare use in the IV fixed-effects case, but a sizeable impact in the pooled cross-section case. Thus, because we are using the IV fixed-effects estimates for the simulations, we find no role for education upgrading in the SSP for NB in the case of high school dropouts, but if we switched to the IV pooled-cross-sectional results the findings would be roughly similar to the NB high school graduate sample.

Tables $7 \mathrm{a}$ and $7 \mathrm{~b}$ illustrate the classic convergence in welfare receipt over time as seen earlier in the actual rates. For high school dropouts, by the 54-month point, predicted (and actual) 
welfare use was essentially the same for program group members as for the control group in BC, but not in NB where a substantial gap of 6 percentage points remains. Our simulation of what welfare rates would have looked like if the program and control groups had done no upgrading to a high school diploma reveals that the 54-month gap would have been 3 percentage points instead of zero in BC - at modestly higher welfare rates of about $65 \%$ for the program group (versus 59\% with upgrading) and 68\% for the control group (versus 59\% with upgrading). For NB in the high school dropout case, the simulated and actual results are about the same. As noted above, this is largely due to the IV-fixed effects coefficient being very small (.027) but also reflects the fact that there was less upgrading in NB than in BC. When we simulate what welfare rates for high school graduates would have looked like if none of these individuals had enrolled in a university, the overall pattern is very similar with roughly an extra 3 percentage points added to the program-control difference in BC. For NB, in this case the welfare receipt differential increases by approximately 1 percentage point (from 6 to 7 points).

Thus, overall, the general income assistance pattern of the program group tapering off after the peak of the “incentive” period (at 18 months) while the control group 'catches up' remains the same even in the absence of educational change over the SSP time period. However, our estimates suggest that in $\mathrm{BC}$ a gap of about 3 percentage points would have existed by the 54-month point if the program group had not been less likely to upgrade their education. There already was a non-trivial gap at the end of the supplement period in NB. These simulation results -- a gap of about 6-7 percentage points in one province and 3 percentage points in the other -province are more suggestive of a small "permanent" effect of the SSP supplement offer than are the experimental estimates, which are influenced by the unintended impact of reduced educational attainment gains in the program group. Whether these modest impacts would persist 
beyond the 54-month point is, of course, an open question. ${ }^{27}$ Further, there may be long-run benefits to generating self-sustaining careers - from university enrolment in particular - that cannot be measured with the SSP time period. Another caveat is that over time more complex work patterns may have emerged.

The simulation results also provide some insight into the large gap between BC and NB in the experimental estimates of the impact of the supplement offer on welfare use. About onehalf of the difference in welfare receipt (approximately 6 percentage points) between the two provinces is attributed by our estimates to the more substantial advances in education in BC than in NB. The results also suggest that education upgrading among long-term welfare recipients plays a reasonably important role in explaining the likelihood of exiting from welfare.

\section{Conclusions}

This paper examines the extent and nature of educational upgrading among participants in the Self-Sufficiency Project. At the outset of the project, all participants were single parents who had been long-term welfare recipients. The paper also investigates the consequences of increases in educational attainment for their propensity to remain on welfare.

There are three principal findings. First, there is a substantial amount of educational upgrading in this population. At the baseline, more than one-half of SSP participants had not completed secondary school. About 19 percent of those who were high school dropouts at the baseline had completed secondary school by the end of the period. There was also substantial activity at the post-secondary level in the form of enrolment in a community college or university.

\footnotetext{
${ }^{27}$ We know from the income assistance records that there was some, albeit small, further convergence in New Brunswick between 54 months and 72 months where the administrative data ends (e.g., see Card and Hyslop 2005). But, we unfortunately cannot know what happened to education after the 54-month point, the last survey.
} 
Second, we find that individuals randomly assigned to the SSP treatment group acquired less additional education during the period than did their counterparts in the control group. The lower levels of human capital acquisition observed in the treatment group are evident at both the secondary school (high school completion) and post-secondary (enrolment in university) levels. Our explanation for this result is that the SSP earnings supplement encouraged treatment group members to exit welfare and take up full-time employment, thus providing less time for other activities, including acquiring additional education. Consistent with this hypothesis, the difference in courses taken between treatments and controls is greatest during the early part of the SSP demonstration when the gap in full-time employment between the two groups was largest. This difference narrows as the differential in employment rates diminishes. In addition to reducing the time available for non-market activities, the financial incentive increased the income that could be earned with existing skills and reduced the return to acquiring additional education.

These findings have potentially important implications for welfare-to-work policies that emphasize a work-first approach. Our results suggest that providing incentives to leave welfare and take up full-time employment may have adverse side effects on human capital acquisition -consequences that need to be weighed against any positive benefits of such policies.

Finally, we provide estimates of the impact of educational upgrading on the incidence of welfare use, and use these estimates to simulate the time paths of welfare receipt in the program and control groups in the absence of advances in educational attainment. Our estimates control for a rich set of observed characteristics as well as unobserved person-specific fixed effects. We also deal with measurement error in educational change using course work completed as an instrumental variable. The IV - FE estimates imply that educational upgrading reduces reliance 
on welfare. Our simulations provide insight into two features of the SSP experimental estimates. One is the apparent absence of a lasting effect of the earnings supplement offer on welfare use, despite large differences between the program and control groups in work activity and income during the supplement period. The simulations suggest that, in the absence of the unintended reduction in educational upgrading in the program group, the SSP financial offer would have reduced welfare use at the end of the supplement period by 3 to 6 percentage points. In addition, the simulations help us to understand the previously unexplained large gap between BC and NB in the estimated experimental impacts. About one-half of the gap appears to be due to the greater prevalence of educational improvement among SSP participants in BC compared to NB. 


\section{References}

Ashenfelter, Orley and Alan Krueger. "Estimates of the Economic Return to Schooling from a New Sample of Twins” American Economic Review 84(December 1994) 1157-73.

Blank, Rebecca. “Evaluating welfare reform in the United States.” Journal of Economic Literature 40 (2002) 1105-1166.

Blank, Rebecca M., David Card and Philip K. Robins. "Financial Incentives for Increasing Work and Income among Low-Income Families" in Finding Jobs: Work and Welfare Reform. New York: Russell Sage Foundation, 2000, pp. 373-419.

Card, David and Dean Hyslop. "Estimating the effects of a time-limited earnings subsidy for welfare-leavers.” Econometrica 73 (2005) 1723-1770.

Hanushek, Eric A. “Non-Labor Supply Responses to the Income Maintenance Experiments” in Lessons from the Income Maintenance Experiments edited by Alicia H. Munnell. Boston: Federal Reserve Bank of Boston Conference Series No. 30, 1986.

Hotz, V. Joseph, Guido W. Imbens and Jacob A. Klerman. "Evaluating the Differential Effects of Alternative Welfare-to-Work Training Components: A Re-Analysis of the California GAIN Program” Journal of Labor Economics 24 (July 2006) 521-566.

Keane, Michael P. and Kenneth I. Wolpin. "Eliminating Race Differences in School Attainment and Labor Market Success” Journal of Labor Economics 18 (October 2000) 614-52.

Keane, Michael P. and Kenneth I. Wolpin. "Estimating Welfare Effects Consistent with Forward-Looking Behavior. Part I: Lessons from a Simulation Exercise” Journal of Human Resources 37 (Summer 2002) 570-599.

Kesselman, Jonathan. “Tax Effects on Job Search, Training and Work Effort” Journal of Public Economics 6 (October 1976) 255-72.

Michalopoulos, Charles, et al. Making Work Pay: Final Report on the Self-Sufficiency Project for Long-Term Welfare Recipients. Ottawa: Social Research and Demonstration Corporation, 2002.

Miller, Robert A. and Seth G. Saunders. "Human capital development and welfare participation” Carnegie-Rochester Conference Series on Public Policy 46 (1997) 1-43.

Moffitt, Robert. "Welfare Programs and Labor Supply” in Handbook of Public Economics volume 4 edited by Alan Auerbach and Martin Feldstein. Amsterdam: Elsevier, 2002.

Robins, Philip K. and Charles Michalopoulos. "Using Financial Incentives to Encourage Welfare Recipients to Become Economically Self-Sufficient” Economic Policy Review, Federal Reserve Bank of New York, September 2001, pp. 105-126. 
Table 1

Baseline summary statistics by high school completion status

\begin{tabular}{|c|c|c|c|c|}
\hline \multirow[t]{2}{*}{ Variable } & \multicolumn{2}{|c|}{ Dropouts at baseline } & \multicolumn{2}{|c|}{ Graduates at baseline } \\
\hline & Treatment group & Control group & Treatment group & Control group \\
\hline British Columbia & $\begin{array}{c}.533 \\
(.014)\end{array}$ & $\begin{array}{c}.535 \\
(.014)\end{array}$ & $\begin{array}{c}.517 \\
(.015)\end{array}$ & $\begin{array}{c}.502 \\
(.016)\end{array}$ \\
\hline Female & $\begin{array}{c}.947 \\
(.006) \\
\end{array}$ & $\begin{array}{c}.953 \\
(.006) \\
\end{array}$ & $\begin{array}{c}.971 \\
(.005) \\
\end{array}$ & $\begin{array}{c}.972 \\
(.005) \\
\end{array}$ \\
\hline Age & $\begin{array}{l}31.84 \\
(.229) \\
\end{array}$ & $\begin{array}{l}31.77 \\
(.231) \\
\end{array}$ & $\begin{array}{l}31.61 \\
(.235) \\
\end{array}$ & $\begin{array}{l}31.74 \\
(.243) \\
\end{array}$ \\
\hline Single, never married & $\begin{array}{c}.510 \\
(.014) \\
\end{array}$ & $\begin{array}{c}.491 \\
(.014) \\
\end{array}$ & $\begin{array}{c}.464 \\
(.015) \\
\end{array}$ & $\begin{array}{c}.489 \\
(.016) \\
\end{array}$ \\
\hline $\begin{array}{l}\text { Years pre-baseline work } \\
\text { experience }\end{array}$ & $\begin{array}{c}6.53 \\
(.175) \\
\end{array}$ & $\begin{array}{c}6.58 \\
(.175) \\
\end{array}$ & $\begin{array}{c}8.29 \\
(.195) \\
\end{array}$ & $\begin{array}{c}8.43 \\
(.193) \\
\end{array}$ \\
\hline Number of children & $\begin{array}{c}1.72 \\
(.024) \\
\end{array}$ & $\begin{array}{c}1.74 \\
(.025)\end{array}$ & $\begin{array}{c}1.62 \\
(.025) \\
\end{array}$ & $\begin{array}{c}1.62 \\
(.027) \\
\end{array}$ \\
\hline Age of youngest child & $\begin{array}{c}6.39 \\
(.139) \\
\end{array}$ & $\begin{array}{c}6.29 \\
(.144) \\
\end{array}$ & $\begin{array}{c}6.14 \\
(.150) \\
\end{array}$ & $\begin{array}{c}5.90 \\
(.160) \\
\end{array}$ \\
\hline $\begin{array}{l}\text { Income assistance over } \\
\text { previous year }\end{array}$ & $\begin{array}{l}11.90 \\
(.008)\end{array}$ & $\begin{array}{l}11.89 \\
(.009)\end{array}$ & $\begin{array}{l}11.88 \\
(.010)\end{array}$ & $\begin{array}{l}11.86 \\
(.012)\end{array}$ \\
\hline Disability & $\begin{array}{l}.210 \\
(.011)\end{array}$ & $\begin{array}{l}.223 \\
(.011) \\
\end{array}$ & $\begin{array}{c}.174 \\
(.011) \\
\end{array}$ & $\begin{array}{l}.160 \\
(.011)\end{array}$ \\
\hline Born outside Canada & $\begin{array}{c}.119 \\
(.009) \\
\end{array}$ & $\begin{array}{l}.115 \\
(.009) \\
\end{array}$ & $\begin{array}{c}.143 \\
(.010) \\
\end{array}$ & $\begin{array}{l}.160 \\
(.011) \\
\end{array}$ \\
\hline Child care required & $\begin{array}{c}.793 \\
(.011) \\
\end{array}$ & $\begin{array}{c}.783 \\
(.011)\end{array}$ & $\begin{array}{c}.800 \\
(.012)\end{array}$ & $\begin{array}{l}.820 \\
(.012) \\
\end{array}$ \\
\hline Likes to work ${ }^{1}$ & $\begin{array}{c}.482 \\
(.013) \\
\end{array}$ & $\begin{array}{c}.471 \\
(.014) \\
\end{array}$ & $\begin{array}{c}.514 \\
(.015) \\
\end{array}$ & $\begin{array}{c}.506 \\
(.015) \\
\end{array}$ \\
\hline $\begin{array}{l}\text { Would like to be going } \\
\text { to school }\end{array}$ & $\begin{array}{l}.580 \\
(.013) \\
\end{array}$ & $\begin{array}{l}.574 \\
(.013) \\
\end{array}$ & $\begin{array}{l}.277 \\
(.013)\end{array}$ & $\begin{array}{c}.286 \\
(.014)\end{array}$ \\
\hline $\begin{array}{l}\text { Ashamed to admit on } \\
\text { welfare }^{3}\end{array}$ & $\begin{array}{c}.604 \\
(.013) \\
\end{array}$ & $\begin{array}{c}.619 \\
(.013) \\
\end{array}$ & $\begin{array}{c}.618 \\
(.015) \\
\end{array}$ & $\begin{array}{c}.633 \\
(.016) \\
\end{array}$ \\
\hline $\begin{array}{l}\text { Wrong to stay on } \\
\text { welfare if you can work }\end{array}$ & $\begin{array}{c}.692 \\
(.013) \\
\end{array}$ & $\begin{array}{c}.714 \\
(.012) \\
\end{array}$ & $\begin{array}{l}.684 \\
(.014) \\
\end{array}$ & $\begin{array}{c}.704 \\
(.014) \\
\end{array}$ \\
\hline Number of observations & 1350 & 1343 & 1110 & 1049 \\
\hline
\end{tabular}

NOTES: Standard errors are in parentheses. The "Dropouts at baseline" sample consists of all individuals who were high school dropouts at the baseline. The "Graduates at baseline" sample consists of all individuals who were high school graduates at the baseline.

1. Agree or strongly agree with the statement "I like going to work"

2. Agree or strongly agree with the statement "Right now I'd really like to be going to school to improve my reading and math skills"

3. Agree or strongly agree with the statement "I am ashamed to admit to people that I am on welfare"

4. Agree or strongly agree with the statement "It's wrong to stay on welfare if you can get a job, even a job you don't like” 
Table 2

Education upgrading in the Self-Sufficiency Project

\begin{tabular}{|c|c|c|c|c|}
\hline Education type & Treatment group & Control group & Difference & $\begin{array}{l}\text { Difference - with } \\
\text { baseline controls }\end{array}$ \\
\hline \multicolumn{5}{|c|}{ (a) Completed high school diploma $(\mathrm{N}=2693)$} \\
\hline Baseline & 0 & 0 & 0 & 0 \\
\hline 18 month & $\begin{array}{c}.068 \\
(.007) \\
\end{array}$ & $\begin{array}{c}.081 \\
(.007) \\
\end{array}$ & $\begin{array}{l}-.013 \\
(.010) \\
\end{array}$ & $\begin{array}{l}-.013 \\
(.010) \\
\end{array}$ \\
\hline 36 month & $\begin{array}{l}.111 \\
(.009)\end{array}$ & $\begin{array}{l}.141 \\
(.009)\end{array}$ & $\begin{array}{l}-.030 \\
(.013)\end{array}$ & $\begin{array}{l}-.030 \\
(.013)\end{array}$ \\
\hline 54 month & $\begin{array}{c}.168 \\
(.010) \\
\end{array}$ & $\begin{array}{c}.209 \\
(.011) \\
\end{array}$ & $\begin{array}{l}-.041 \\
(.015)\end{array}$ & $\begin{array}{l}-.041 \\
(.015)\end{array}$ \\
\hline \multicolumn{5}{|c|}{ (b) Enrolled in a university $(\mathrm{N}=2159)$} \\
\hline Baseline & 0 & 0 & 0 & 0 \\
\hline 18 month & $\begin{array}{c}.008 \\
(.003)\end{array}$ & $\begin{array}{c}.017 \\
(.004)\end{array}$ & $\begin{array}{l}-.009 \\
(.005)\end{array}$ & $\begin{array}{l}-.009 \\
(.005)\end{array}$ \\
\hline 36 month & $\begin{array}{c}.014 \\
(.004)\end{array}$ & $\begin{array}{l}.028 \\
(.006)\end{array}$ & $\begin{array}{l}-.014 \\
(.006)\end{array}$ & $\begin{array}{l}-.014 \\
(.006)\end{array}$ \\
\hline 54 month & $\begin{array}{c}.026 \\
(.005)\end{array}$ & $\begin{array}{c}.044 \\
(.007)\end{array}$ & $\begin{array}{l}-.018 \\
(.008)\end{array}$ & $\begin{array}{l}-.018 \\
(.008)\end{array}$ \\
\hline
\end{tabular}

NOTES: Standard errors are in parentheses. The sample in panel (a) consists of all individuals who were high school dropouts at the baseline. The sample in panel (b) consists of all individuals who were high school graduates at the baseline. 
Table 3

Educational upgrading by province

\begin{tabular}{|c|c|c|c|c|c|c|}
\hline & \multicolumn{6}{|c|}{ High school dropouts obtaining high school diploma } \\
\hline & \multicolumn{3}{|c|}{ British Columbia $(\mathrm{N}=1438)$} & \multicolumn{3}{|c|}{ New Brunswick $(\mathrm{N}=1255)$} \\
\hline & Program & Control & Difference & Program & Control & Difference \\
\hline Baseline & 0 & 0 & 0 & 0 & 0 & 0 \\
\hline 18 month & $\begin{array}{c}.084 \\
(.010)\end{array}$ & $\begin{array}{c}.103 \\
(.011)\end{array}$ & $\begin{array}{l}-.019 \\
(.015)\end{array}$ & $\begin{array}{l}.049 \\
(.009)\end{array}$ & $\begin{array}{l}.054 \\
(.009)\end{array}$ & $\begin{array}{l}-.005 \\
(.012)\end{array}$ \\
\hline 36 month & $\begin{array}{l}.126 \\
(.012)\end{array}$ & $\begin{array}{c}.166 \\
(.013)\end{array}$ & $\begin{array}{c}-.040 \\
(.018)\end{array}$ & $\begin{array}{c}.093 \\
(.012) \\
\end{array}$ & $\begin{array}{r}.112 \\
(.013)\end{array}$ & $\begin{array}{c}-.018 \\
(.017)\end{array}$ \\
\hline \multirow[t]{4}{*}{54 month } & $\begin{array}{c}.190 \\
(.015)\end{array}$ & $\begin{array}{c}.247 \\
(.016)\end{array}$ & $\begin{array}{c}-.057 \\
(.021)\end{array}$ & $\begin{array}{c}.140 \\
(.014)\end{array}$ & $\begin{array}{c}.166 \\
(.015)\end{array}$ & $\begin{array}{l}-.026 \\
(.020)\end{array}$ \\
\hline & \multicolumn{6}{|c|}{ High school graduates enrolling in university } \\
\hline & \multicolumn{3}{|c|}{ British Columbia $(\mathrm{N}=1100)$} & \multicolumn{3}{|c|}{ New Brunswick $(\mathrm{N}=1059)$} \\
\hline & Program & Control & Difference & Program & Control & Difference \\
\hline Baseline & 0 & 0 & 0 & 0 & 0 & 0 \\
\hline 18 month & $\begin{array}{c}.004 \\
(.003)\end{array}$ & $\begin{array}{c}.020 \\
(.006)\end{array}$ & $\begin{array}{l}-.016 \\
(.007)\end{array}$ & $\begin{array}{c}.013 \\
(.005)\end{array}$ & $\begin{array}{c}.014 \\
(.006)\end{array}$ & $\begin{array}{l}-.001 \\
(.008)\end{array}$ \\
\hline 36 month & $\begin{array}{l}.016 \\
(.005)\end{array}$ & $\begin{array}{c}.031 \\
(.008)\end{array}$ & $\begin{array}{l}-.015 \\
(.010)\end{array}$ & $\begin{array}{c}.013 \\
(.005)\end{array}$ & $\begin{array}{c}.025 \\
(.007)\end{array}$ & $\begin{array}{c}-.012 \\
(.009)\end{array}$ \\
\hline 54 month & $\begin{array}{c}.028 \\
(.007) \\
\end{array}$ & $\begin{array}{c}.052 \\
(.010)\end{array}$ & $\begin{array}{c}-.024 \\
(.012) \\
\end{array}$ & $\begin{array}{c}.024 \\
(.007) \\
\end{array}$ & $\begin{array}{c}.035 \\
(.008)\end{array}$ & $\begin{array}{l}-.011 \\
(.011)\end{array}$ \\
\hline
\end{tabular}

Notes: Standard errors are in parentheses. 
Table 4

Income assistance rates by high school completion status and province

\begin{tabular}{|c|c|c|c|c|c|c|}
\hline & \multicolumn{6}{|c|}{ High school dropout sample } \\
\hline & \multicolumn{2}{|c|}{ Pooled } & \multicolumn{2}{|c|}{ British Columbia } & \multicolumn{2}{|c|}{ New Brunswick } \\
\hline & Programs & Controls & Programs & Controls & Programs & Controls \\
\hline Baseline & .994 & .996 & .990 & .993 & 1.000 & 1.000 \\
\hline 18 month & .721 & .848 & .747 & .851 & .692 & .845 \\
\hline 36 month & .678 & .748 & .669 & .723 & .687 & .776 \\
\hline 54 month & .622 & .650 & .588 & .589 & .662 & .720 \\
\hline \multirow[t]{3}{*}{$\mathrm{N}$} & 1350 & 1343 & 720 & 718 & 630 & 625 \\
\hline & \multicolumn{6}{|c|}{ High school graduate sample } \\
\hline & \multicolumn{2}{|c|}{ Pooled } & \multicolumn{2}{|c|}{ British Columbia } & \multicolumn{2}{|c|}{ New Brunswick } \\
\hline Baseline & .994 & .990 & .989 & .980 & 1.000 & 1.000 \\
\hline 18 month & .566 & .722 & .643 & .778 & .483 & .665 \\
\hline 36 month & .497 & .572 & .565 & .608 & .425 & .535 \\
\hline 54 month & .426 & .465 & .472 & .484 & .378 & .446 \\
\hline $\mathrm{N}$ & 1110 & 1049 & 574 & 526 & 536 & 523 \\
\hline
\end{tabular}


Table 5 (a)

Estimated coefficients of the change in probability of receiving income assistance: British Columbia

\begin{tabular}{|c|c|c|c|c|c|c|c|c|}
\hline & \multicolumn{4}{|c|}{ High School Dropouts } & \multicolumn{4}{|c|}{ High School Graduates } \\
\hline & OLS & IV & Fixed-effects & $\begin{array}{l}\text { IV Fixed- } \\
\text { effects }\end{array}$ & OLS & IV & Fixed-effects & $\begin{array}{l}\text { IV Fixed- } \\
\text { effects }\end{array}$ \\
\hline $\begin{array}{l}\text { Completed } \\
\text { high school }\end{array}$ & $\begin{array}{c}-.128 * * * \\
(.017)\end{array}$ & $\begin{array}{c}-.309 * * * \\
(.101)\end{array}$ & $\begin{array}{c}-.110 * * * \\
(.021)\end{array}$ & $\begin{array}{l}-.357^{*} \\
(.199)\end{array}$ & - & - & - & - \\
\hline $\begin{array}{l}\text { Enrolled in } \\
\text { university }\end{array}$ & - & - & - & - & $\begin{array}{c}-.085 * * * \\
(.020)\end{array}$ & $\begin{array}{c}-.593 * * * \\
(.150)\end{array}$ & $\begin{array}{c}-.083 * * \\
(.030)\end{array}$ & $\begin{array}{l}-.640 * \\
(.357)\end{array}$ \\
\hline $\begin{array}{l}\text { Baseline } \\
\text { controls }\end{array}$ & Yes & Yes & No & No & Yes & Yes & No & No \\
\hline Time dummies & Yes & Yes & Yes & Yes & Yes & Yes & Yes & Yes \\
\hline $\begin{array}{l}\text { SSP * time } \\
\text { dummies }\end{array}$ & Yes & Yes & Yes & Yes & Yes & Yes & Yes & Yes \\
\hline R squared & .12 & .12 & .14 & .10 & .18 & .07 & .18 & .09 \\
\hline $\begin{array}{l}\text { First stage F- } \\
\text { statistic }\end{array}$ & - & 71.6 & - & 106.6 & - & 40.6 & - & 85.5 \\
\hline $\begin{array}{l}\text { Number of } \\
\text { observations }\end{array}$ & 5752 & 5525 & 5752 & 5525 & 4400 & 4268 & 4400 & 4268 \\
\hline $\begin{array}{l}\text { Number of } \\
\text { individuals }\end{array}$ & 1438 & 1438 & 1438 & 1438 & 1100 & 1100 & 1100 & 1100 \\
\hline
\end{tabular}

NOTES: Robust standard errors in parentheses. ${ }^{* * *}$ denotes significance at $1 \%, * *$ at $5 \%$ and $*$ at $10 \%$. 
Table 5 (b)

Estimated coefficients of the change in probability of receiving income assistance: New Brunswick

\begin{tabular}{|c|c|c|c|c|c|c|c|c|}
\hline & \multicolumn{4}{|c|}{ High School Dropouts } & \multicolumn{4}{|c|}{ High School Graduates } \\
\hline & OLS & IV & Fixed-effects & $\begin{array}{l}\text { IV Fixed- } \\
\text { effects }\end{array}$ & OLS & IV & Fixed-effects & $\begin{array}{l}\text { IV Fixed- } \\
\text { effects }\end{array}$ \\
\hline $\begin{array}{l}\text { Completed } \\
\text { high school }\end{array}$ & $\begin{array}{c}-.142 * * * \\
(.021)\end{array}$ & $\begin{array}{c}-.282 * * * \\
(.078)\end{array}$ & $\begin{array}{c}-.105^{* * * *} \\
(.025)\end{array}$ & $\begin{array}{c}.027 \\
(.141) \\
\end{array}$ & - & - & - & - \\
\hline $\begin{array}{l}\text { Enrolled in } \\
\text { university }\end{array}$ & - & - & - & - & $\begin{array}{c}-.109 * * * \\
(.020)\end{array}$ & $\begin{array}{c}-.278 * * * \\
(.078)\end{array}$ & $\begin{array}{c}-.101 * * * \\
(.031)\end{array}$ & $\begin{array}{l}-.309 * \\
(.192) \\
\end{array}$ \\
\hline $\begin{array}{l}\text { Baseline } \\
\text { controls }\end{array}$ & Yes & Yes & No & No & Yes & Yes & No & No \\
\hline Time dummies & Yes & Yes & Yes & Yes & Yes & Yes & Yes & Yes \\
\hline $\begin{array}{l}\text { SSP * time } \\
\text { dummies }\end{array}$ & Yes & Yes & Yes & Yes & Yes & Yes & Yes & Yes \\
\hline $\begin{array}{l}\text { First stage F- } \\
\text { statistic }\end{array}$ & - & 80.1 & - & 84.5 & - & 67.1 & - & 102.2 \\
\hline R-squared & .11 & .10 & .11 & .10 & .24 & .23 & .24 & .23 \\
\hline $\begin{array}{l}\text { Number of } \\
\text { observations }\end{array}$ & 5020 & 4903 & 5020 & 4903 & 4236 & 4173 & 4236 & 4173 \\
\hline $\begin{array}{l}\text { Number of } \\
\text { individuals }\end{array}$ & 1255 & 1255 & 1255 & 1255 & 1059 & 1059 & 1059 & 1059 \\
\hline
\end{tabular}

NOTES: Robust standard errors in parentheses. *** denotes significance at $1 \%$, ** at $5 \%$ and $*$ at $10 \%$. 
Table 6

Falsification test

\begin{tabular}{|c|c|c|c|}
\hline \multirow[t]{2}{*}{$\begin{array}{l}\text { Treatment } \\
\text { sample: }\end{array}$} & \multicolumn{3}{|c|}{$\begin{array}{l}\text { OLS estimated coefficients for effect of high school completion } \\
\text { on future welfare use: By upgrading cohort }\end{array}$} \\
\hline & $\begin{array}{c}\text { On welfare at } 18 \\
\text { months }\end{array}$ & $\begin{array}{c}\text { On welfare at } 36 \\
\text { months }\end{array}$ & $\begin{array}{c}\text { On welfare at } 54 \\
\text { months }\end{array}$ \\
\hline $\begin{array}{l}\text { Upgraded } \\
\text { between baseline- } \\
18 \text { months } \\
\end{array}$ & $\begin{array}{l}-.102 * * * \\
(.030)\end{array}$ & $\begin{array}{c}-.159 * * * \\
(.033)\end{array}$ & $\begin{array}{c}-215^{* * *} \\
(.035)\end{array}$ \\
\hline $\begin{array}{l}\text { Upgraded } \\
\text { between } 18 \\
\text { months-36 } \\
\text { months }\end{array}$ & - & $\begin{array}{c}-.089 * * \\
(.039)\end{array}$ & $\begin{array}{l}-.118 * * * \\
(.042)\end{array}$ \\
\hline \multirow[t]{3}{*}{$\begin{array}{l}\text { Upgraded } \\
\text { between } 36 \\
\text { months-54 } \\
\text { months } \\
\end{array}$} & - & - & $\begin{array}{l}-.105 * * * \\
(.038)\end{array}$ \\
\hline & \multicolumn{3}{|c|}{$\begin{array}{l}\text { Pre-treatment alignment tests: OLS estimated coefficients for } \\
\text { effect of high school completion on past welfare use }\end{array}$} \\
\hline & $\begin{array}{c}\text { On welfare at } \\
\text { baseline }\end{array}$ & $\begin{array}{c}\text { On welfare at } 18 \\
\text { months }\end{array}$ & $\begin{array}{c}\text { On welfare at } 36 \\
\text { months }\end{array}$ \\
\hline $\begin{array}{l}\text { Upgraded } \\
\text { between baseline- } \\
18 \text { months }\end{array}$ & $\begin{array}{l}-.000 \\
(.005)\end{array}$ & - & - \\
\hline $\begin{array}{l}\text { Upgraded } \\
\text { between } 18 \\
\text { months-36 } \\
\text { months }\end{array}$ & $\begin{array}{c}-.003 \\
(.006)\end{array}$ & $\begin{array}{c}-.049 \\
(.036)\end{array}$ & - \\
\hline $\begin{array}{l}\text { Upgraded } \\
\text { between } 36 \\
\text { months-54 } \\
\text { months }\end{array}$ & $\begin{array}{c}-.001 \\
(.005)\end{array}$ & $\begin{array}{c}.008 \\
(.032)\end{array}$ & $\begin{array}{c}-.042 \\
(.036)\end{array}$ \\
\hline
\end{tabular}


Table 7(a)

Simulations of income assistance receipt under no high school upgrading: By province

\begin{tabular}{|c|c|c|c|c|c|c|c|c|}
\hline Time & \multicolumn{4}{|c|}{ British Columbia } & \multicolumn{4}{|c|}{ New Brunswick } \\
\hline & \multicolumn{2}{|c|}{ Predicted } & \multicolumn{2}{|c|}{ Simulated with no upgrading } & \multicolumn{2}{|c|}{ Predicted } & \multicolumn{2}{|c|}{ Simulation with no upgrading } \\
\hline & Programs & Controls & Programs & Controls & Programs & Controls & Programs & Controls \\
\hline Baseline & .992 & .992 & .992 & .992 & 1.000 & 1.000 & 1.000 & 1.000 \\
\hline 18 month & .751 & .850 & .781 & .887 & .692 & .845 & .691 & .843 \\
\hline 36 month & .672 & .719 & .717 & .778 & .687 & .777 & .685 & .773 \\
\hline 54 month & .585 & .589 & .646 & .677 & .660 & .717 & .657 & .712 \\
\hline
\end{tabular}

Table 7(b)

Simulations of income assistance receipt under no university enrolment: By province

\begin{tabular}{|c|c|c|c|c|c|c|c|c|}
\hline Time & \multicolumn{4}{|c|}{ British Columbia } & \multicolumn{4}{|c|}{ New Brunswick } \\
\hline & \multicolumn{2}{|c|}{ Predicted } & \multicolumn{2}{|c|}{ Simulated with no upgrading } & \multicolumn{2}{|c|}{ Predicted } & \multicolumn{2}{|c|}{ Simulation with no upgrading } \\
\hline & Programs & Controls & Programs & Controls & Programs & Controls & Programs & Controls \\
\hline Baseline & .986 & .986 & .986 & .986 & 1.000 & 1.000 & 1.000 & 1.000 \\
\hline 18 month & .640 & .785 & .725 & .893 & .483 & .665 & .533 & .719 \\
\hline 36 month & .555 & .615 & .646 & .730 & .426 & .536 & .476 & .592 \\
\hline 54 month & .474 & .484 & .570 & .609 & .379 & .441 & .430 & .500 \\
\hline
\end{tabular}




\section{Appendix}

\section{Measurement error}

We first document the extent of measurement error in the educational attainment questions, and our approach to addressing this error. To preview the results of this exercise, we emphasize that the results are highly robust to different choices, despite non-trivial differences in sample size across the samples associated with these choices.

Table A1 shows all combinations of responses to the high school graduation questions. The responses are divided into two main groups, referred to as "consistent responses" and "inconsistent responses." Consistency here refers to responses that accord with the fact that educational attainment can increase but cannot decrease over time. For example, we label as "inconsistent" someone who stated at the baseline survey that they had graduated from high school but who responded to a later survey that they had not completed high school. The consistent responses are further broken down into "No upgrading" and "Upgrading" categories. Inconsistent responses are also separated into two sub-groups. "Majority cases" are those in which one survey response differs from the responses to the other three surveys. In these circumstances the single outlier may be a coding error or response error. "Non-majority cases" are those for which the responses are evenly divided between Yes and No in a manner that is not logically consistent. Finally, we show at the bottom those cases where there was either a missing response to the high school question or where an individual dropped out for a survey. In almost all of these cases the individual did not respond to the entire survey (as opposed to not responding to the education question). For brevity we leave out the full set of permutations for the missing cases, but ultimately we use this data in our analysis.

In the case of high school, about $8 \%$ of the total sample report in at least one of the surveys that their education declined. However, most of these involve cases where three of the four surveys match up. One way to address this error would be to drop from the sample individuals with inconsistent responses. Although this approach has some appeal, we cannot presume that all of the consistent responses are measured without error. Perhaps more importantly, a quick review of Table A1 reveals that if you drop inconsistent cases you mechanically increase the extent of upgrading.

Our approach in creating the main sample for analysis (i.e., the samples used in Table 2 of the paper) is to assume that the individual misreported cases where one response was 
inconsistent with the rest. For example, from Table A1 row 6, we assume that the 'Yes' reported at the baseline is a mistake and should be a 'No'. This exercise therefore converts rows 6, 10, and 11 to counterfactual potential upgraders while rows 7, 8, and 9 are assumed to be high school graduates and are thus excluded from our high school analysis. For non-majority cases, it is unclear what decision rule to adopt. Rather than dropping these observations for our main sample used in the analysis, we simply assume the baseline is correct. For our sensitivity checks below, we also do the analysis excluding these cases (i.e., rows 12-14 are considered high school graduates, and thus not used in the high school analysis while rows 15 and 16 are considered potential upgraders with row 15 being a counterfactual case, and row 16 being classified as an upgrader).

We perform this same exercise for cases where an individual missed a survey. For the missing surveys, this does not end up being all that important - 543 of the 581 individuals who missed one survey had all other education responses consistent with each other (e.g., [0, missing, $0,0]$ and so forth).

We must make some assumptions about the timing of upgrading for those individuals missing responses (or surveys). For instance, in an upgrading case of [0, missing, 1, 1] we must make an assumption about whether the individual upgraded at 18 months or at 36 months. For our main upgrading variable (which equals one if the individual completed high school at some point) this is irrelevant, but we also do some analysis that exploits the timing of the upgrading. Fortunately, there are only 11 of such cases in the case of high school completion. As a decision rule, we always assume the upgrading occurs later (i.e., in the example above the missing is a zero and the individual is assumed to upgrade at 36 months).

Finally, we conduct our analysis across all four possible techniques of addressing the measurement error: a) using only non-missing consistent responses, b) using only non-missing consistent responses plus majority inconsistent responses, c) using all non-missing responses, and d) our principal sample of using all data. Table A2 shows the sensitivity of the high school experimental impacts to these alternative choices. The experimental impact ranges from -3.9 to -4.2 percentage points (-4.1 for our preferred sample).

We omit the university results here, but there was very little evidence of measurement error in the case of enrolment in university. 
Appendix Table A1

Responses to high school attainment question over SSP $(\mathbf{N}=4852)$

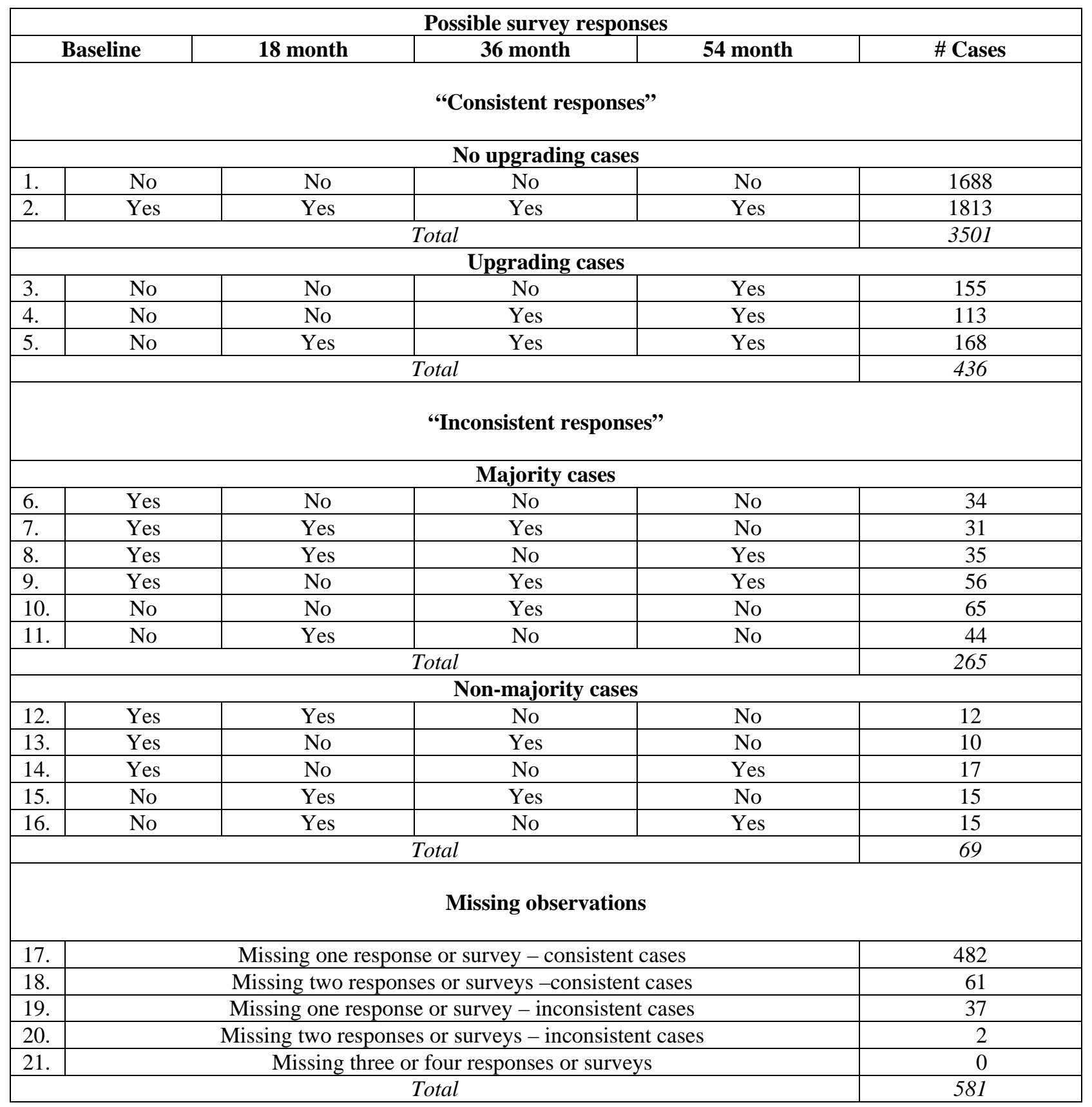

NOTES: The complete SSP data consists of 5978 observations. SSP+ individuals (293 observations) and individuals not reporting to the 54 month survey (833 observations) are deleted from the sample. Our sample is therefore 4852 observations. 
Appendix Table A2

High school completion across different samples

\begin{tabular}{|c|c|c|c|}
\hline Education type & Treatment group & Control group & Difference \\
\hline \multicolumn{4}{|c|}{ Sample using only 'consistent responses', no missing surveys $(\mathrm{N}=2124)$} \\
\hline Baseline & 0 & 0 & - \\
\hline 18 month & $\begin{array}{c}.070 \\
(.008) \\
\end{array}$ & $\begin{array}{c}.088 \\
(.008) \\
\end{array}$ & $\begin{array}{c}-.018 \\
(.012) \\
\end{array}$ \\
\hline 36 month & $\begin{array}{c}.116 \\
(.010)\end{array}$ & $\begin{array}{c}.148 \\
(.011)\end{array}$ & $\begin{array}{c}-.032 \\
(.015)\end{array}$ \\
\hline 54 month & $\begin{array}{c}.184 \\
(.011) \\
\end{array}$ & $\begin{array}{c}.226 \\
(.012) \\
\end{array}$ & $\begin{array}{c}-.042 \\
(.018) \\
\end{array}$ \\
\hline \multicolumn{4}{|c|}{ Sample using 'consistent responses' plus 'majority of responses consistent', no missing ( $N=2267$} \\
\hline Baseline & 0 & 0 & - \\
\hline 18 month & $\begin{array}{c}.066 \\
(.007) \\
\end{array}$ & $\begin{array}{c}.082 \\
(.008) \\
\end{array}$ & $\begin{array}{c}-.016 \\
(.011) \\
\end{array}$ \\
\hline 36 month & $\begin{array}{c}.109 \\
(.009)\end{array}$ & $\begin{array}{c}.139 \\
(.010)\end{array}$ & $\begin{array}{c}-.030 \\
(.014)\end{array}$ \\
\hline 54 month & $\begin{array}{c}.172 \\
(.011) \\
\end{array}$ & $\begin{array}{c}.212 \\
(.012) \\
\end{array}$ & $\begin{array}{c}-.040 \\
(.017) \\
\end{array}$ \\
\hline \multicolumn{4}{|c|}{ Sample using all responses except missing surveys ( $N=2297)$} \\
\hline Baseline & 0 & 0 & - \\
\hline 18 month & $\begin{array}{c}.074 \\
(.008) \\
\end{array}$ & $\begin{array}{c}.085 \\
(.008)\end{array}$ & $\begin{array}{c}-.011 \\
(.011)\end{array}$ \\
\hline 36 month & $\begin{array}{c}.121 \\
(.010) \\
\end{array}$ & $\begin{array}{c}.150 \\
(.010) \\
\end{array}$ & $\begin{array}{l}.029 \\
(.014) \\
\end{array}$ \\
\hline 54 month & $\begin{array}{c}.174 \\
(.011) \\
\end{array}$ & $\begin{array}{c}.213 \\
(.012) \\
\end{array}$ & $\begin{array}{c}.039 \\
(.017) \\
\end{array}$ \\
\hline \multicolumn{4}{|c|}{ Final sample: Sample using all responses $(\mathrm{N}=2693)$} \\
\hline Baseline & 0 & 0 & - \\
\hline 18 month & $\begin{array}{c}.067 \\
(.007)\end{array}$ & $\begin{array}{c}.080 \\
(.007)\end{array}$ & $\begin{array}{c}-.013 \\
(.010)\end{array}$ \\
\hline 36 month & $\begin{array}{c}.110 \\
(.009) \\
\end{array}$ & $\begin{array}{c}.140 \\
(.009) \\
\end{array}$ & $\begin{array}{c}-.030 \\
(.013) \\
\end{array}$ \\
\hline 54 month & $\begin{array}{c}.167 \\
(.010) \\
\end{array}$ & $\begin{array}{c}.208 \\
(.011) \\
\end{array}$ & $\begin{array}{c}-.041 \\
(.015) \\
\end{array}$ \\
\hline
\end{tabular}

NOTES: Standard errors are in parentheses. 
Appendix Table A3

Mean baseline characteristics for high school dropout sample

\begin{tabular}{|l|c|c|c|c|}
\hline & \multicolumn{2}{|c|}{ British Columbia } & \multicolumn{2}{c|}{ New Brunswick } \\
\hline Variable & $\begin{array}{c}\text { Remained } \\
\text { dropout }\end{array}$ & $\begin{array}{c}\text { Completed } \\
\text { diploma }\end{array}$ & $\begin{array}{c}\text { Remained } \\
\text { dropout }\end{array}$ & $\begin{array}{c}\text { Completed } \\
\text { diploma }\end{array}$ \\
\hline Female & .952 & .952 & .945 & .958 \\
& $(.006)$ & $(.012)$ & $(.007)$ & $(.014)$ \\
\hline Age & 31.93 & 30.61 & 32.80 & 27.48 \\
& $(.243)$ & $(.446)$ & $(.269)$ & $(.548)$ \\
\hline Single & .478 & .476 & .502 & .656 \\
& $(.015)$ & $(.028)$ & $(.015)$ & $. .034)$ \\
\hline Years pre-baseline work & 6.85 & 7.31 & 6.11 & 5.22 \\
experience & $(.189)$ & $(.378)$ & $(.198)$ & $(.407)$ \\
\hline Number of children & 1.82 & 1.73 & 1.67 & 1.58 \\
& $(.028)$ & $(.049)$ & $(.027)$ & $(.059)$ \\
\hline Age of youngest child & 5.85 & 5.39 & 7.42 & 4.79 \\
& $(.148)$ & $(.274)$ & $(.167)$ & $.332)$ \\
\hline Income assistance over & 11.89 & 11.85 & 11.92 & 11.90 \\
previous year & $(.010)$ & $(.023)$ & $(.008)$ & $(.022)$ \\
\hline Disability & .225 & .197 & .230 & .120 \\
& $(.012)$ & $(.022)$ & $(.013)$ & $(.023)$ \\
\hline Born outside Canada & .215 & .159 & .019 & .017 \\
& $(.012)$ & $(.021)$ & $(.004)$ & $. .009)$ \\
\hline Child care required & .806 & .825 & .743 & .869 \\
& $(.012)$ & $(.021)$ & $(.013)$ & $(.024)$ \\
\hline Likes to work & .467 & .400 & .509 & .480 \\
& $(.015)$ & $(.028)$ & $(.015)$ & $(.036)$ \\
\hline Would like to be going to & .599 & .511 & .566 & .615 \\
school & $(.015)$ & $(.028)$ & $(.015)$ & $. .035)$ \\
\hline Ashamed to admit on welfare & .641 & .638 & .574 & .609 \\
& $(.014)$ & $(.027)$ & $(.015)$ & $(.035)$ \\
\hline Wrong to stay on welfare if you & .638 & .662 & .762 & .781 \\
can work & $(.014)$ & $(.026)$ & $(.013)$ & $(.029)$ \\
\hline Number of observations & 1123 & 315 & 1063 & 192 \\
\hline
\end{tabular}

NOTES: Standard errors are in parentheses. 